\title{
THE EFFECTS OF FINANCIAL RATIO AND MARKET BASED RATIO TOWARD THE STOCK PRICE OF MANUFACTURING INDUSTRY SECTOR IN INDONESIA STOCK EXCHANGE
}

\author{
Mulyono \\ Management Department, School of Business Management, BINUS University \\ Jln. K.H. Syahdan No.9, Palmerah, Jakarta Barat 11480 \\ D4998@binus.ac.id
}

\begin{abstract}
The research objectives to examine the magnitude of the significant influence between financial ratios and the market based ratio toward the stock price of manufacturing industry sector in Indonesia Stock Exchange (IDX). In accordance IDX data by December 2013, the number of companies, included in the stock of the manufacturing industry sector, is 139 companies. Based on the analysis, it is concluded that the variable return on assets (ROA) and price to book value (PBV) has positive influence on stock prices. It can be interpreted that the higher the return on assets ratio and price to book value, the more positive influence on the increase of the stock price. The variable debt to equity ratio (DER) and price earnings ratio (PER) has negatively influence the stock price on the stock of manufacturing industry sector. This can be interpreted the higher the value of the debt to equity ratio and price earnings ratio, the more negatively influence on the decrease stock price.
\end{abstract}

Keywords: Indonesia Stock Exchange, manufacturing industry sector, financial ratio

\begin{abstract}
ABSTRAK
Penelitian bertujuan untuk menguji besarnya pengaruh signifikan antara rasio keuangan dan rasio penilaian pasar terhadap harga saham yang berada di sektor industri manufaktur pada Bursa Efek Indonesia (BEI). Sesuai data BEI per Desember 2013 jumlah perusahaan yang termasuk dalam saham sektor industri manufaktur sebanyak 139 perusahaan. Berdasarkan analisis disimpulkan bahwa variabel return on assets (ROA) dan price to book value (PBV) memiliki pengaruh yang positif terhadap harga saham, hal tersebut dapat diintrepetasikan semakin tinggi nilai rasio return on asset serta price to book value maka semakin positif pengaruh pada peningkatan harga saham. Pada variabel debt to equity ratio (DER) dan price earning ratio (PER) berpengaruh negatif terhadap harga saham pada sektor industri manufaktur. Hal tersebut dapat diintrepetasikan semakin tinggi nilai debt to equity ratio serta price earning ratio maka semakin negatif pengaruh pada penurunan harga saham.
\end{abstract}

Kata kunci: Bursa Efek Indonesia, sector industry manufaktur, rasio keuangan 


\section{PENDAHULUAN}

Pasar Modal merupakan pasar dimana berbagai instrument keuangan jangka panjang dapat diperdagangkan baik dalam bentuk surat hutang maupun modal (ekuitas). Pasar modal yang ada di Indonesia menjadi salah satu faktor penting dalam rangka meningkatkan pertumbuhan ekonomi nasional, hal tersebut karena melalui pasar modal perusahaan dapat mencari pendanaan untuk meningkatkan kondisi keuangan perusahaan. Pada saat perusahaan mencari pendanaan dipasar modal maka mekanisme yang terjadi yaitu pemodal yang memiliki kelebihan dana memberikan dana yang dimiliki untuk diinvestasikan pada perusahaan yang tercatat di bursa. Dalam melakukan investasi tersebut, pemodal mengharapkan imbal hasil dan emiten dapat memanfaatkan dana untuk berbagai kegiatan operasional perusahaan.

Sesuai dengan Buku Panduan Indeks Harga Saham Bursa Efek Indonesia (Bursa Efek Indonesia, 2010), perusahaan yang mencatatkan sahamnya pada Bursa Efek Indonesia (BEI) dibagi menjadi sembilan sektor yaitu sektor pertanian, sektor pertambangan, sektor industri dasar dan kimia, sektor aneka industri, sektor industri barang konsumsi, sektor properti dan real estate, sektor transportasi dan infrastruktur, sektor keuangan, sektor perdagangan, jasa dan investasi. Perusahaan yang termasuk sektor industri manufaktur merupakan gabungan dari perusahaan yang terdapat pada sektor industri dasar dan kimia, sektor aneka industri, sektor industri barang konsumsi. Berdasarkan data BEI per Desember 2013 (Bursa Efek Indonesia, 2013), jumlah perusahaan yang termasuk dalam sektor industri manufaktur adalah 139 perusahaan.

Tabel 1 Jumlah Perusahaan dalam Klasifikasi Industri BEI per Desember 2013

\begin{tabular}{lc}
\multicolumn{1}{c}{ Klasifikasi Industri } & Perusahaan \\
\hline A. Sektor-sektor Primer (Ekstraktif) & $\mathbf{5 9}$ \\
\hline Sektor Pertanian & 20 \\
Sektor Pertambangan & 39 \\
\hline B. Sektor-sektor Sekunder (Industri Pengolahan / Manufaktur) & $\mathbf{1 3 9}$ \\
\hline Sektor Industri Dasar dan Kimia & 60 \\
Sektor Aneka Industri & 41 \\
Sektor Industri Barang Konsumsi & 38 \\
\hline C. Sektor-sektor Tersier (Industri Jasa / Non-manufaktur) & $\mathbf{2 8 9}$ \\
\hline Sektor Properti dan Real Estate & 54 \\
Sektor Transportasi dan Infrastruktur & 47 \\
Sektor Keuangan & 78 \\
Sektor Perdagangan, Jasa dan Investasi & 110 \\
\hline \multicolumn{2}{c}{ Jumlah ( A + B + C) } \\
\hline
\end{tabular}

Sumber: Bursa Efek Indonesia, data diolah.

Pada perdagangan dibursa, harga saham dapat bergerak naik maupun turun. Harga saham yang berfluktuasi tersebut menurut Darmadji dan Hendy (2008) karena ada permintaan dan penawaran terhadap saham. Permintaan dan penawaran tersebut dapat terjadi dikarenakan adanya berbagai faktor, baik faktor yang memiliki sifat yang spesifik untuk saham tersebut misalnya kinerja perusahaan serta industri di mana perusahaan tersebut berada, maupun berbagai faktor yang bersifat makro seperti kondisi perekonomian suatu negara, kondisi sosial dan politik serta perkembangan informasi lainnya. Selanjutnya menurut Husnan (2001) apabila perusahaan memiliki kemampuan yang meningkat dalam menghasilkan laba, maka hal tersebut dapat meningkatkan harga saham. Dengan kata lain meningkatnya profitabilitas perusahaan akan mempengaruhi harga saham. 
Berbagai penelitian menunjukkan adanya hubungan antara keadaan keuangan perusahaan, yaitu rasio keuangan dan rasio pasar dengan harga saham perusahaan tersebut dibursa. Penelitian yang dilakukan Tse (2002) pada empat saham real estate besar dibursa saham Hong Kong, menunjukkan bahwa dividend yield berpengaruh pada tingkat yang rendah, sedangkan relatif tinggi pada price earning ratio terhadap harga saham perusahaan. Mohanty (2002) mengemukakan bahwa variabel kapitalisasi pasar, market leverage, price to book value (PBV) dan price to earning ratio (PER) memiliki korelasi yang tinggi terhadap return saham pada bursa saham India. Selanjutnya Rahmani et. al (2006), melakukan penelitian dengan hasil menunjukkan bahwa debt to equity ratio (DER) tidak berpengaruh secara signifikan, sedangkan variabel lainnya yaitu price to book value (PBV), price to earning ratio (PER), dan sale to price ratios memiliki pengaruh yang signifikan terhadap return saham pada bursa efek Teheran, Iran.

Penelitian mengenai hubungan antara rasio keuangan dan rasio pasar terhadap harga saham pada Bursa Efek Indonesia yang telah dilakukan sebelumnya adalah penelitian yang dilakukan Susilowati dan Turyanto (2011) yang menguji pengaruh faktor fundamental yaitu earning per share (EPS), net profit margin (NPM), return on asset (ROA), return on equity (ROE) dan debt to equity ratio (DER) terhadap imbal hasil saham pada perusahaan manufaktur yang terdaftar di Bursa Efek Indonesia. Hasil penelitian menunjukkan DER memiliki pengaruh yang signifikan terhadap imbal hasil saham. Sedangkan variabel EPS, NPM, ROA dan ROE tidak memiliki pengaruh signifikan terhadap imbal hasil saham. Selanjutnya Arista dan Astohar (2012) mengemukakan return on asset (ROA) dan earning per share (EPS) tidak berpengaruh signifikan pada imbal hasil saham perusahaan manufaktur di Bursa Efek Indonesia, sedangkan debt to equity ratio (DER) dan price to book value (PBV) memiliki pengaruh signifikan. Secara bersama-sama (simultan) ROA, DER, EPS dan PBV memiliki pengaruh signifikan terhadap imbal hasil saham pada perusahaan manufaktur di Bursa Efek Indonesia.

Berdasarkan latar belakang yang telah disampaikan maka permasalahan dalam penelitian ini adalah apakah rasio keuangan dan rasio pasar memiliki pengaruh yang signifikan terhadap harga saham pada sektor industri manufaktur di Bursa Efek Indonesia. Penelitian ini memiliki tujuan untuk menguji besarnya pengaruh signifikan antara rasio keuangan dan rasio pasar terhadap harga saham pada sektor industri manufaktur di Bursa Efek Indonesia. Penelitian ini diharapkan dapat memberi manfaat untuk praktisi dan akademisi. Untuk praktisi, penelitian ini dapat dijadikan acuan untuk memilih saham yang terdaftar pada sektor industri manufaktur sebagai alternatif pilihan investasi. Untuk akademisi, penelitian ini diharapkan dapat memberikan kontribusi yang positif untuk penelitian dibidang pasar modal khususnya penelitian dibidang harga saham.

\section{Saham}

Pengertian saham menurut Jones (2010) merupakan surat berharga yang merepresentasikan kepemilikan dalam perusahaan. Bursa Efek Indonesia dalam website-nya (www.idx.co.id) menjelaskan bahwa saham merupakan tanda penyertaan modal seseorang atau pihak (badan usaha) dalam suatu perusahaan, sehingga dengan adanya penyertaan modal maka pihak tersebut memiliki klaim atas pendapatan perusahaan serta klaim atas aset perusahaan, dan pihak tersebut berhak hadir pada Rapat Umum Pemegang Saham (RUPS).

\section{Jenis-jenis rasio keuangan}

Rasio keuangan merupakan nilai yang diperoleh dari hasil perbandingan antara satu pos pada laporan keuangan dengan pos lain yang berkaitan secara relevan dan signifikan (Harahap, 2002). Dalam penelitian ini rasio keuangan yang digunakan adalah rasio return on equity, dan debt to equity ratio, untuk rasio penilaian pasar yang digunakan adalah price earning ratio dan price to book value ratio. 
Rasio Keuangan merupakan angka yang diperoleh dari hasil perbandingan dari satu pos laporan keuangan dengan pos lainnya yang mempunyai hubungan yang relevan, sehingga rasio keuangan menjadi penting dalam melakukan analisa terhadap kondisi keuangan perusahaan (Ross et al., 2012; Harahap, 2002). Rasio keuangan ini terdiri dari: (1) Return on Assets (ROA) menunjukkan besarnya jumlah laba bersih yang dihasilkan perusahaan apabila diukur dari jumlah asset. (2) Debt Equity Ratio (DER), rasio ini menunjukkan perbandingan antara hutang terhadap ekuitas.

$$
\begin{aligned}
& \text { Return on Aset }=\frac{\text { Laba bersih }}{\text { Total } \text { Aset }} \\
& \text { Debt to equity ratio }=\frac{\text { Total hutang }}{\text { Total ekuitas }}
\end{aligned}
$$

Rasio Penilaian Pasar (Market Based Ratio) merupakan rasio yang umumnya digunakan pada pasar modal, jenis rasio ini menggambarkan harga saham perusahaan dibursa dibandingkan dengan keadaan keuangan perusahaan, rasio yang termasuk dalam jenis rasio penilaian pasar (Market Based Ratio) adalah: (1) Price Earning Ratio (PER). Rasio ini menunjukkan seberapa besar perbandingan antara harga saham yang tercatat di bursa dengan laba per saham berdasarkan laporan keuangan perusahaan, (2) Price to Book Value Ratio (PBV). Rasio ini merupakan nilai yang dihasilkan dari perbandingan antara harga saham perusahaan di bursa dengan nilai buku saham sesuai dengan yang tercantum dalam laporan keuangan.

$$
\begin{aligned}
& \text { Price Earning Ratio }=\frac{\text { Harga saham }}{\text { Laba bersih per saham }} \\
& \text { Price Book Value Ratio }=\frac{\text { Harga saham }}{\text { Nilai buku saham }}
\end{aligned}
$$

\section{Klasifikasi Sektor Industri}

Seluruh perusahaan yang tercatat di BEI dikategorikan dalam sembilan sektor industri sesuai dengan klasifikasi industri yang ditetapkan oleh BEI. Klasifikasi industri tersebut dikenal dengan nama JASICA (Jakarta Industrial Classification). Dengan demikian klasifikasi sektor industri manufaktur (industri pengolahan) terdiri dari perusahaan yang termasuk dalam sektor industri dasar dan kimia, sektor aneka industri serta sektor industri barang konsumsi. Sesuai dengan data yang diperoleh dari Bursa Efek Indonesia (2010) sektor industri tersebut sebagai berikut: (1) Sektor-sektor Primer (Ekstraktif) terdiri dari sektor pertanian, sektor pertambangan. (2) Sektor-sektor Sekunder (Industri Pengolahan/Manufaktur) terdiri dari sektor industri dasar dan kimia, sektor aneka industri, sektor industri barang konsumsi. (3) Sektor-sektor Tersier (Industri Jasa/Non-manufaktur) terdiri dari sektor properti dan real estate, sektor transportasi dan infrastruktur, sektor keuangan, sektor perdagangan, jasa dan investasi.

Hipotesis yang akan diajukan pada penelitian ini adalah sebagai berikut:

$\mathrm{H}_{1}$ : Terdapat pengaruh yang signifikan antara return on asset (ROA) terhadap harga saham pada sektor industri manufaktur. 
$\mathrm{H}_{2}$ : Terdapat pengaruh yang signifikan antara debt to equity ratio (DER) terhadap harga saham pada sektor industri manufaktur.

$\mathrm{H}_{3}$ : Terdapat pengaruh signifikan antara price earning ratio (PER) terhadap harga saham pada sektor industri manufaktur.

$\mathrm{H}_{4}$ : Terdapat pengaruh signifikan antara price to book value ratio (PBV) terhadap harga saham pada sektor industri manufaktur.

Dalam pengujian hipotesis menggunakan program SPSS versi 20, dilakukan dengan menggunakan angka signifikansi. Keputusan yang diperoleh menggunakan kriteria berikut ini:

Apabila angka signifikansi yang diperoleh hasil penelitian $<0,05$ maka keputusannya $\mathrm{H}_{0}$ ditolak.

Apabila angka signifikansi yang diperoleh hasil penelitian $>0,05$ maka keputusannya $\mathrm{H}_{0}$ diterima.

\section{METODE}

Populasi dalam penelitian ini adalah perusahaan dengan saham sebagai anggota sektor industri Manufaktur. Jenis data merupakan data sekunder yang diperoleh dari Bursa Efek Indonesia dan Indonesian Capital Market Electronic Library (ICaMEL). Periode dalam penelitian ini adalah akhir tahun 2013, berdasarkan periode penelitian tersebut jumlah data $(\mathrm{N})$ yang akan diteliti adalah sebanyak 139 data.

Teknik analisa yang dilakukan dalam penelitian ini adalah model regresi linear berganda, yang ditujukan untuk memperhitungkan dan menganalisa secara kuantitatif hubungan setiap variable independen yaitu rasio return on asset (ROA), rasio debt to equity (DER), rasio price to earning (PER) dan rasio price to book value (PBV), dengan variabel dependen yaitu harga saham yang termasuk dalam indeks saham manufaktur, hubungan tersebut dapat dijelaskan secara sistematis sebagai berikut:

$$
Y=a+\beta 1 R O A+\beta 2 D E R+\beta 3 P E R+\beta 4 P B V+e
$$

Definisi operasional variabel yang digunakan dalam penelitian ini adalah:

$Y \quad$ adalah Harga saham yang termasuk dalam sektor industri manufaktur

a adalah konstanta

$\beta 1, \beta 2, \beta 3, \beta 4$ adalah koefisien variabel ROA, DER, PER, PBV

ROA adalah rasio return on asset

DER adalah rasio debt to equity

PER adalah rasio price to earning

PBV adalah rasio price to book value

$e \quad$ adalah standard error

Proses analisis yang akan dilakukan terdiri dari penghitungan koefisien regresi dari variabel independen secara individu (uji t), pengujian variabel independen secara bersama-sama (uji F), serta pengujian goodness of fit test $\left(\mathrm{R}^{2}\right)$. 


\section{HASIL DAN PEMBAHASAN}

Berdasarkan pengolahan data menggunakan program SPSS versi 20, didapatkan hasil sebagai berikut:

Tabel 2 Descriptive Statistics

\begin{tabular}{lrrr}
\hline & \multicolumn{1}{c}{ Mean } & Std. Deviation & N \\
\hline PRICE & 18154.0576 & 110227.71770 & 139 \\
ROA & 5.6910 & 10.97106 & 139 \\
DER & 2.2641 & 13.37154 & 139 \\
PER & 18.8361 & 70.00047 & 139 \\
PBV & 2.6248 & 5.48122 & 139 \\
\hline \multicolumn{2}{c}{ Sumber: hasil olah data menggunakan SPSS versi 20 }
\end{tabular}

Pada analisis regresi yang dilakukan akan menghasilkan sebuah persamaan regresi, yang merupakan suatu formula untuk menghitung nilai variabel dependen berdasarkan nilai variabel independen yang diketahui. Pada penelitian ini data yang digunakan sebagai variabel dependen adalah harga saham (price), dan data yang digunakan sebagai variabel independen adalah rasio return on aset, rasio debt to equity, rasio price to earning dan rasio price to book value. Sesuai dengan jumlah dalam indeks saham sektor manufaktur adalah 139 saham, dengan demikian $\mathrm{N}$ dalam penelitian ini adalah berjumlah 139 .

Tabel 3 Hasil Olah Data Menggunakan Uji t

\begin{tabular}{rcrcccc}
\hline \multirow{2}{*}{ Model } & \multicolumn{2}{c}{ Unstandardized Coefficients } & Standardized Coefficients & \multirow{2}{*}{ T } & \multirow{2}{*}{ Sig. } \\
\cline { 2 - 5 } & \multicolumn{1}{c}{ B } & Std. Error & Beta & & -2.139 & .034 \\
& (Constant) & -19196.897 & 8975.623 & & 3.720 & .000 \\
1 & ROA & 3219.217 & 865.434 & -.022 & -.292 & .771 \\
& DER & -179.911 & 616.862 & -.025 & -.363 & .717 \\
& PER & -39.221 & 107.911 & .382 & 4.445 & .000 \\
\hline
\end{tabular}

a. Dependent Variable: PRICE

Sumber: hasil olah data menggunakan SPSS versi 20

Berdasarkan hasil olah data diperoleh persamaan regresi sebagai berikut:

$Y=-19.196,90+3.219,22(\mathrm{ROA})-179.91(\mathrm{DER})-39.22(\mathrm{PER})+7.686,76(\mathrm{PBV})$

Pada persamaan regresi dapat diperoleh kesimpulan bahwa variabel ROA memiliki pengaruh yang positif dan signifikan (nilai Sig. $<0,05$ ) terhadap harga saham, kemudian variabel DER berpengaruh negatif dan tidak signifikan (nilai Sig. $>0,05$ ), selanjutnya variabel PER berpengaruh negatif dan tidak signifikan (nilai Sig. $>0,05$ ), dan variabel PBV berpengaruh positif dan signifikan (nilai Sig. $<0,05$ ) terhadap harga saham. Dengan demikian hipotesa $\mathrm{H}_{1}$ dan $\mathrm{H}_{4}$ diterima sedangkan $\mathrm{H}_{2}$ dan $\mathrm{H}_{3}$ ditolak. 


\section{Pengujian Kebaikan Suai (goodness of fit test)}

Nilai $\mathrm{R}^{2}$ atau koefisien determinasi merupakan nilai yang digunakan untuk mengukur berapa persen (\%) dari variasi variabel dependen yang dapat dijelaskan oleh variasi dari variabel independen. Hasil olah data menunjukkan nilai Adjusted R Square adalah 0,357 hal tersebut berarti bahwa 35,7\% dari variabel harga saham dapat dijelaskan oleh variabel ROA, DER, PER dan PBV, sedangkan sisanya dijelaskan oleh faktor lainnya.

Tabel 4 Hasil Olah Data Menggunakan Uji Goodness of Fit Test

\begin{tabular}{ccccc}
\hline Model & R & R Square & Adj. R Square & Std. Error of the Estimate \\
\hline 1 & $.613^{\mathrm{a}}$ & .375 & .357 & 88411.19428 \\
\hline
\end{tabular}

a. Predictors: (Constant), PBV, PER, DER, ROA

Sumber: hasil olah data menggunakan SPSS versi 20

\section{Pengujian secara bersama-sama (Uji F)}

Pengujian secara bersama-sama atau Uji $\mathrm{F}$ digunakan untuk mengetahui apakah semua variable independen yang digunakan dalam penelitian secara bersama-sama dapat berpengaruh terhadap variabel dependen. Hipotesa yang digunakan pada Uji F sebagai berikut:

$\mathrm{H}_{0}$ : Variabel independen yaitu ROA, DER, PER dan PBV secara bersama-sama tidak memiliki pengaruh yang signifikan terhadap harga saham pada sektor industri manufaktur.

$\mathrm{H}_{\mathrm{a}}$ : Variabel independen yaitu ROA, DER, PER dan PBV secara bersama-sama memiliki pengaruh yang signifikan terhadap harga saham pada sektor industri manufaktur.

Dengan menggunakan nilai $\alpha=5 \%, \mathrm{n}_{1}=4$ dan $\mathrm{n}_{2}=139$, diperoleh nilai $\mathrm{F}$ tabel yaitu 2,37 (Sekaran, 2000). Hasil penghitungan olah data diperoleh nilai $\mathrm{F}$ hitung adalah sebesar 20,13 dengan tingkat signifikansi 0,000 . Dengan demikian $\mathrm{F}$ hitung lebih besar dari $\mathrm{F}$ tabel maka $\mathrm{H}_{0}$ ditolak, sehingga pada penelitian ini variabel ROA, DER, PER dan PBV secara bersama-sama mempengaruhi harga saham pada sektor industri manufaktur secara signifikan.

Tabel 5 Hasil Olah Data Menggunakan Uji F

\begin{tabular}{llrrrrr}
\hline & Model & Sum of Squares & \multicolumn{1}{c}{ Df } & \multicolumn{1}{c}{ Mean Square } & \multicolumn{1}{c}{ F } & \multicolumn{1}{c}{ Sig. } \\
\hline & Regression & 629304402787.598 & 4 & 157326100696.900 & 20.127 & $.000^{\mathrm{b}}$ \\
1 & Residual & 1047416262639.942 & 134 & 7816539273.432 & & \\
Total & 1676720665427.541 & 138 & & & \\
\hline
\end{tabular}

a. Dependent Variable: PRICE

b. Predictors: (Constant), PBV, PER, DER, ROA

\section{SIMPULAN}

Penelitian ini bertujuan untuk mengetahui pengaruh rasio keuangan dan rasio penilaian pasar terhadap harga saham pada sektor industri manufaktur. Berdasarkan analisis yang telah dilakukan, variabel ROA dan PBV memiliki pengaruh yang positif terhadap harga saham. Hasil tersebut dapat diintrepetasikan bahwa semakin tinggi nilai ROA dan PBV maka dapat mempunyai pengaruh positif dan meningkatkan harga saham. 
Pada variabel DER dan PER mempunyai pengaruh yang negatif terhadap harga saham pada sektor industri manufaktur. Hal tersebut dapat diintrepetasikan semakin tinggi nilai DER dan PER maka dapat memiliki pengaruh negatif serta dapat menurunkan harga saham. Saran yang diberikan untuk penelitian selanjutnya adalah dengan menggunakan harga saham yang tercatat pada berbagai sektor industri lainnya yang terdapat pada BEI, misalnya menggunakan data harga saham pada sektor pertambangan atau sektor keuangan, dapat pula menggunakan saham yang termasuk dalam indeks LQ 45.

\section{DAFTAR PUSTAKA}

Arista, D., Astohar. (2012). Analisis Faktor Faktor yang Mempengaruhi Return Saham. Jurnal Ilmu Manajemen dan Akuntansi Terapan. 3(1): 1-15.

Bursa Efek Indonesia. (2010). Buku Panduan Indeks Harga Saham Bursa Efek Indonesia. Jakarta: Bursa Efek Indonesia.

Bursa Efek Indonesia. (2013). IDX Statistics, edisi Desember 2013. Jakarta: Bursa Efek Indonesia

Darmadji, T., Hendy M. F. (2008). Pasar Modal di Indonesia Pendekatan Tanya Jawab. Edisi 2. Jakarta: Salemba Empat.

Harahap, S. S. (2002). Analisis Kritis Atas Laporan Keuangan. Jakarta: Raja Grasindo Persada.

Husnan, S. (2001). Dasar Dasar Teori Portofolio dan Analisis Sekuritas. Edisi 3. Yogyakarta: UPP AMP YKPN.

Jones, C. P. (2010). Investments Principles and Concepts. Asia: John Wiley \& Sons.

Mohanty, P. (2002). Evidence of Size Effect on Stock Returns in India. Vikalpa Journal, 27(3): 27-37.

Rahmani, A., Sauber, S., Elnaz, T. (2006). Accounting Variables, Market Variables and Stock Return in Emerging Markets: Case of Iran. Faculty of Management \& Accounting, Allameh Tabataba'i University, Teheran-Iran.

Ross, S., A., Randolph, W. W., Bradford, D. J., Joseph, L., Ruth, T. (2012). Fundamentals of Corporate Finance. Asia Global Edition. McGraw-Hill Companies Inc.

Sekaran, U. (2000). Research Methods For Business. USA: John Wiley \& Sons Inc.

Susilowati, Y., Tri, T. (2011). Reaksi Signal Rasio Profitabilitas dan Rasio Solvabilitas Terhadap Return Saham Perusahaan. Jurnal Dinamika Keuangan dan Perbankan, 3(1): 17 - 37.

Tse, R. Y. C. (2002). Price-Earnings Ratios, Dividend Yields and Real Estate Stock Prices. Journal of Real Estate Portfolio Management, 8(2): 107-113. 